\title{
Traktat o manekinach, czyli - Bruno Schulz wykłada o sztuce
}

\section{Maria Olędzka (Olomouc)}

\begin{abstract}
Abstrakt
Celem niniejszego artykułu jest analiza i interpretacja jednego z opowiadań Brunona Schulza zatytułowanego Traktat o manekinach albo Wtóra Księga Rodzaju, a przede wszystkim - przedstawienie jego spojrzenia na proces twórczy i rolę artysty.

\section{Słowa kluczowe}

Bruno Schulz; Traktat o manekinach albo Wtóra Księga Rodzaju; manekin; Księga Rodzaju; stworzenie człowieka; rola artysty; sztuka

\section{Abstract \\ A Treatise on Mannequins, or Bruno Schulz talks about Art}

The purpose of this article is to analyse and to interpret one of the stories, written by Bruno Schulz, titled $A$ Treatise on Mannequins, or The Second Book of Genesis, but primarily - introduction of his view on the process of creation and the role of the artist.
\end{abstract}

\section{Key words}

Bruno Schulz; A Treatise on Mannequins, or The Second Book of Genesis; mannequin; Genesis; creation of a man; the role of the artist; art 
Traktat o manekinach albo Wtóra Ksiega Rodzaju, jak sam tytuł wskazuje, odnosi się do biblijnej Ksiegi Rodzaju, a konkretnie - do opisu stworzenia świata. Jednak nie jest to powtórzenie treści zawartych w Pięcioksięgu, lecz ich druga wersja; „wtórna”, alternatywna. W tym opowiadaniu Jakub (będący jednym z alter ego Autora) wykłada swoją teorię o kreacyjnych możliwościach człowieka; artysty. Stąd też bierze się określenie „Wtóra Księga Rodzaju”, gdyż jak postuluje Jakub - dzieła człowieka zawsze są wtórne wobec dzieł Boga. Jednak jeśli weźmiemy pod uwagę, że losy biblijnego Jakuba zostały opisane właśnie w Księdze Rodzaju, to sam ten fakt przydaje nowe znaczenie. Poprzez ten gest Jakub Schulza, będący odbiciem, „parafrazą” swojego biblijnego imiennika, przestaje być biernym uczestnikiem wydarzeń, a staje się „stwórca” swojego losu, ale i losów (nowego) świata.

Jakub określa Boga mianem Demiurgosa. Termin ten wywodzi się z greckiego słowa „dēmiourgós”. Pierwotnie nazywano tak każdego rzemieślnika, ale o ile był niezależny, a później - każdego twórcę. Drugie znaczenie pochodzi z Timaiosa. W tym dziele Platon określił mianem „demiurga” boskiego budowniczego świata, który nadaje określoną formę wiecznej, ale „nieokreślonej”, materii. ${ }^{1}$

Jakub postuluje możliwość kreacji dostępną nie tylko Demiurgosowi, ale wszystkim istniejącym istotom duchowym; każdemu człowiekowi. On sam pragnie stać się demiurgiem, choć wypowiada się także w imieniu bliżej nieokreślonych „innych”, którym jakoby przewodniczy. Nie chce konkurować z Bogiem. Nie pragnie demiurgii „doskonałej” (boskiej), ale - „wtórej”; na miarę możliwości człowieka. Chce, by jego dzieła były nietrwałe, prowizoryczne, wręcz - tandetne. Jakub postuluje: "Jeśli będa to ludzie, to damy im na przyktad tylko jedna strone twarzy, jedna ręke, jedna noge, te mianowicie, która im będzie w ich roli potrzebna. [...] Z tytu moga być po prostu zaszyte ptótnem lub pobielone. Nasza ambicje poktadać będziemy w dumnej dewizie: dla każdego gestu inny aktor."2

Zatem dzieła te, w jego zamierzeniu, mają być jednowymiarowe, „płaskie”; tak jak obrazy malarzy; tak jak wszelkie dzieła sztuki. Jakub okazuje się artystą, ale artystą świadomym swoich ograniczeń, czy też widzącym w tychże ograniczeniach swoją „odmienność”, „oryginalność”, a może nawet siłę: „Demiurgos kochat się w wytrawnych, doskonatych i skomplikowanych materiatach - my dajemy pierwszeństwo tandecie. [...] Czy rozumiecie [...] gtęboki sens tej stabości, tej pasji do pstrej bibutki, do "papier mâché«, do lakowej farby, do ktaków i trociny? To jest [...] nasza mitość do materii jako takiej [...]."3

Tym samym Jakub ustawia się w opozycji do dzieł boskich, które są w swej istocie idealne, albo w opozycji do ekspresjonizmu, który w swoich założeniach opowiada się po stronie „ducha”. Jak stwierdza Jerzy Jarzębski - boskie kreacje są identyczne same ze sobą. Z kolei dzieła ludzkie są „semantycznie dwudzielne”; składają się z materii i nadanego jej przez twórcę znaczenia ${ }^{4}$. Z tego też powodu nie mogą być inne niż „prowizoryczne”, niedoskonałe. Ponadto - będą one zawsze „martwe”, bo pozbawione boskiego

1 JARZĘBSKI, Jerzy: Czasoprzestrzeń mitu i marzenia w prozie Brunona Schulza. W: tegoż: Powieść jako autokreacja. Kraków: Wydawnictwo Literackie, 1984, s. 215.

2 SCHULZ, Bruno: Opowiadania. Wybór esejów i listów. Kraków: Zakład Narodowy im. Ossolińskich, 1989, s. 35.

3 Ibidem, s. 35-36.

4 JARZĘBSKI, Jerzy: Op. cit., s. 215-216. 
tchnienia. Jednak Jakub nie dostrzega w tym ułomności, czy też może raczej - ułomność tę gloryfikuje; czyni swoim głównym postulatem. Jego („ich”) cel jest konkretny: „- Stowem - konkludowat mój ojciec - chcemy stworzyć po raz wtóry cztowieka, na obraz i podobieństwo manekina." ${ }^{5}$

Fragment ten można zrozumieć dwojako. Pewne jest, że Jakub, tak jak Bóg, chce stworzyć człowieka, z tą różnicą, że nie na swoje podobieństwo. Nowy człowiek ma być wzorowany na manekinie, a "manekin” to określenie stosowane wobec człowieka bezwolnego lub człowieka o twarzy niewyrażającej żadnych uczuć. Manekin to także symbol „człowieka bez właściowści”; pierwowzór lub „uniwerslny” wzór człowieka. Być może na tym zasadza się „występność” planu Jakuba; gdyż jego zamierzenia są jakby parodią boskiej kreacji. Ale można też założyć, że Jakub chce (na wzór Boga) stwarzać za pomoca słów. Jednak, jak wyznaje, nie zna boskich sposobów (recept) twórczych; nie zna słów, za pomocą których mógłby powołać do życia samoistnie odnawiający się świat. Dlatego zamierza tworzyć posługując się metodami „heretyckimi”; będzie nadawać materii nowe kształty i „nowe sensy”. Z drugiej strony sam fakt, że bohater odrzuca „ducha”, a staje po stronie materii, uzasadniałby nazwanie jego postulatów „herezjami”, choć określenia tego nie można czytać dosłownie.

Według Władysława Panasa w teoriach Jakuba można dopatrzyć się powiązań z żydowską legendą o Golemie ${ }^{6}$. Jak podaje ów badacz - motyw ten uzyskał popularność w literaturze głównie dzięki niemieckim romantykom, choć pojawił się w kulturze żydowskiej już ok. III-VI wieku. Historia o Golemie posiada wiele wersji, jednak ta najbardziej znana wiąże się z postacią czeskiego rabina, zarazem kabalisty i alchemika, który jakoby w XVI wieku ulepił z gliny postać ludzką i posługując się metodami (formułami) magicznymi - nadał jej życie. Legenda głosi, że Golem nie potrafił ani mówić, ani myśleć; wypełniał jedynie rozkazy. Został stworzony, by pomagać narażonej na prześladowania nacji żydowskiej. Jak stwierdza Panas - topos Golema można odczytywać różnie. Jego zdaniem przede wszystkim wyraża ludzką chęć poznania tajemnicy stworzenia świata i człowieka (Bożego „słowa sprawczego”), a tym samym przywłaszczenia sobie Jego mocy.

Nie bez znaczenia jest to, do kogo Jakub kieruje swoje prelekcje. Otóż, przemawia głównie do Poldy i Pauliny, dziewcząt wynajętych do szycia. Dlaczego to właśnie one stały się „wyznawczyniami” jego teorii? Są to przede wszystkim kobiety, czyli te, które dają życie, a ponadto - krawcowe, czyli te, które nadają kształt materii. Pracują dla Jakuba, który jest właścicielem sklepu z materiałami. Innymi słowy - współtworzą razem z nim nowy świat, ale ich zadanie jest inne niż jego. One tworzą z tego, co już jest (z nieukształtowanej materii). Są demiurgami w platońskim znaczeniu tego słowa. Szyją ubrania, formując je na manekinie. Ubranie nadaje człowiekowi określoną tożsamość, podkreśla status czy indywidualność; w jakiś sposób klasyfikuje. Jakub, jak już wiemy, chce stworzyć człowieka na wzór manekina, czyli pewien model, uniwersalny „szkielet”, FORME, która posłuży szwaczkom. Może samą ideę człowieka, duszę; niezmienną wewnętrzną istotę. W myśl poglądu, że ciało jest ubraniem duszy.

5 SCHULZ, Bruno: Op. cit., s. 36.

6 PANAS, Władysław: Topika judajska. W: Stownik literatury polskiej XX wieku. Red. Janusz Sławiński. Wrocław: Zakład Narodowy im. Ossolińskich, 1992, s. 1202-1103. 
W opowiadaniu Manekiny czytamy, że Jakub spotyka Poldę i Paulinę pewnego wieczora przy pracy, gdy krzątają się wokół kobiecego manekina - idola, drapując na nim kawałki kolorowych materiałów. Podczas opisu ich postaci narrator przyrównuje je do egzotycznych ptaków - papug, które, jak podaje Władysław Kopaliński, symbolizują naśladownictwo ${ }^{7}$. Także Jakub czyni takie spostrzeżenie na ich temat: „- Genus avium [...] jeśli sie nie myle, scansores albo pistacci [...] w najwyższym stopniu godne uwagi." ${ }^{8}$

Są więc one barwnymi ptakami, artystkami, nieświadomymi demiurgami - przekształcają materię, nadając jej nowe kształty, tak jak Jakub w Ptakach. Zarazem opis ich powierzchowności wskazuje na jakieś podobieństwo do manekinów: mają „tandetne ciałka”, oczy jak z emalii. Zdają się być żywym wcieleniem postulatów Jakuba. Któż zatem może być lepszym odbiorca jego teorii niż one właśnie?

W swoim wykładzie ojciec Józefa wypowiada się także na temat materii. Podziwia jej niekończąca się płodność i nieograniczone możliwości kreacyjne. Jak stwierdza już na początku swojego wywodu: jest ona w swej istocie nieokreślona i bezkształtna, całkowicie bierna i bezbronna, dlatego też można ją dowolnie formować i deformować: „Nie ma $\dot{z} a d n e g o$ zła w redukcji życia do form innych i nowych. Zabójstwo nie jest grzechem. Jest ono nieraz koniecznym gwattem wobec opornych i skostniatych form bytu, które przestaty być zajmujace. [...] Tu jest punkt wyjścia dla nowej apologii sadyzmu." 9

Dlaczego zabójstwo materii nie jest grzechem? Ponieważ, jak stwierdza bohater, coś takiego jak martwa materia nie istnieje: „[...] martwota jest jedynie pozorem, za którym ukrywaja sie nieznane formy życia. ${ }^{10}$

Zatem „zabicie” materii z logicznego punktu widzenia jest niemożliwe. Z kolei - czym jest owa „apologia sadyzmu”? Jest to pochwała dla idei rozbijania starych i tworzenia nowych form; czyż nie brzmi to jak apologia sztuki (awangardowej)?

Za sprawa Adeli, przemówienie Jakuba zostaje przerwane. Tym razem kusi go ona niczym rajski wąż: „[...] podniosta brzeg sukni, wystawita powoli stopę, opięta w czarny jedwab, i wyprężyta ja jak pyszczek węża."11

W rezultacie Jakub porzuca rolę „natchnionego herezjarchy” i pada do jej stóp; ponownie zostaje pokonany (poniżony) przez materię, którą symbolizuje kobieta i która tak bardzo go fascynuje.

W następnym opowiadaniu, będącym kontynuacją Traktatu o manekinach, Józef relacjonuje dalszy ciąg wywodów ojca. Tym razem herezjarcha mówi o woskowych figurach z panoptikum, „kalwaryjskich parodiach manekinów” i o pałubach, które cierpią z powodu narzuconej im roli, a raczej jej niezmienności; jednoznaczności. Bohater poucza swoje audytorium o tym, że materię należy traktować poważnie; w żadnym wypadku nie należy z niej żartować. „Żartowanie” z materii w tej sytuacji miałoby polegać na „zamykaniu”

7 KOPALIŃSKI Władysław: Stownik symboli. Warszawa: Rytm, 2001, s. 501.

8 SCHULZ, Bruno: Op. cit., s. 31. Jak podano w przypisach - łacińskie słowa użyte w tym fragmencie („Genus avium [...] scansores [...] pistacci"; właśc. psittaci) znaczą tyle co: 'rodzina ptaków [...] (rząd) laźców [...] (rząd) papug'.

9 Ibidem, s. 33.

10 Ibidem, s. 34.

11 Ibidem, s. 36. 
jej, czy też w niej, jednego gestu, grymasu; na przypisywaniu jej cudzej „osobowości” czy też obcych jej właściwości, na „szufladkowaniu”: „Nadajecie jakiejś gtowie z ktaków i ptótna wyraz gniewu i pozostawiacie ja z tym gniewem, z ta konwulsja, z tym napięciem raz na zawsze, zamknięta ze ślepa ztościa, dla której nie ma odptywu."12

Jakub określa takie działania mianem sadyzmu i bezprawia. Jednocześnie wzywa swoje słuchaczki do zastanowienia się nad losem tak "gnębionej” materii; wzywa je do dostrzeżenia pewnych podobieństw z ich własnym życiem; każdy został przecież „zamknięty” w jakiejś niezmiennej, materialnej formie, która na zawsze go określa. Swoje przesłanie omawia na przykładzie woskowych figur, które przedstawiają jakichś znanych, wielkich ludzi. Wspomina o postaciach: Lucchesiniego, królowej Dragi czy genialnego młodzieńca onanisty. W jego mniemaniu figury te sa jedynie parodią owych osób; twórca nadaje im nazwę, a tym samym tożsamość - fałszywą, bo jednoznaczną: „Czy jest w tej pałubie coś naprawde z królowej Dragi, jej sobowtór, najdalszy bodaj cień jej istoty? To podobieństwo, ta nazwa uspokaja nas i nie pozwala nam pytać, kim jest dla siebie samego ten twór nieszczésliwy. A jednak to musi ktoś być, moje panie, ktoś anonimowy, ktoś groźny, ktoś nieszczéśliwy, ktoś, co nie styszat nigdy w swym gtuchym życiu o królowej Dradze..."13

Być może Jakub mówi o wewnętrznej istocie każdego człowieka. Być może nawiązuje do Gombrowicza i jego koncepcji formy, od której nie sposób się uwolnić, a tym samym do teorii Freuda o destrukcyjnym wpływie kultury, która „więzi” człowieka. A może mówi o sztuce, która w swoich próbach odzwierciedlania rzeczywistości staje się, według niego, „śmieszna”. Z tego mogłoby wynikać, że Jakub postuluje odrzucenie sztuki realistycznej. Staje po stronie materii (futuryzmu). O możliwości takiej interpretacji prelekcji Jakuba świadczą słowa, które wypowiada w Manekinach: „Gdybym, odrzucajac respekt przed Stwórca, chciat sie zabawić w krytyke stworzenia, wołatbym: - mniej treści, więcej formy!" 14

Czyż nie jest to postulat wprost z manifestu Tytusa Czyżewskiego: „Artyści będa jak najmniej używać tematu, a jak najwięcej konstruować. Artyści będa kierować się instynktem." 15

Owe „fałszywe tożsamości” pałub można odczytać także, w kontekście słów Northropa Frye‘a, jako „uosobienia” mitów, dzieł lub postaci literackich: „Literatura, podobnie jak mitologia, jest w znacznej mierze sztuka zwodniczych analogii i mylnych tożsamości."16

Warto zaznaczyć, że Jakub nie wlicza manekinów w poczet materii „gnębionej”; prawdopodobnie dlatego, że manekiny odznaczają się brakiem cech charakterystycznych, wyróżniających, a przez to nie są ,jednoznaczne”. Manekin jest prototypem żywego człowieka - modela ${ }^{17}$, czy też w kontekście literatury - inspiracji, z której twórca czerpie tworząc.

12 Ibidem, s. 38.

13 Ibidem, s. 39.

14 Ibidem, s. 31.

15 CZYŻEWSKI, Tytus: Pogrzeb romantyzmu - uwiąd starczy symbolizmu - śmierć programizmu. W: Antologia polskiego futuryzmu i Nowej Sztuki. Oprac. Zbigniew Jarosiński i Helena Zaworska. Wrocław: Zakład Narodowy im. Ossolińskich, 1978, s. 41.

16 FRYE, Northrop: Mit, fikcja i przemieszczenie. W: Studia z teorii literatury. Archiwum przektadów »Pamiętnika Literackiego«. Wrocław: Zakład Narodowy im. Ossolińskich, 1977, s. 303.

17 LACHMANN, Renate: Demiurg i jego fantazmaty. Spekulacje wokót mitologii stworzenia w dziele Bruno Schulza. Tłum. Jan Balbierz. Teksty Drugie, 1999, nr 6, s. 107. 
Pisarz tworzy postaci swoich utworów podobnie jak malarz: „[...] nie ma u jego bohaterów takiego gestu, tiku, akcentu, których jego natchnieniu nie przyniostaby pamieć; nie ma takiego nazwiska postaci fikcyjnej, pod które nie mógtby podstawić sześćdziesięciu nazwisk osób znajomych - z których ten pozowat do grymasu twarzy, tamten do monokla, inny do gniewu, jeszcze inny do wytwornego ruchu ręka etc." 18

Jakub, postulując stworzenie człowieka na wzór manekina, tym samym czyni z niego model dla wykreowania postaci literackiej. Zauważa (tak jak Proust), że na każda postać literacką składa się wielu ludzi; „[...] dla każdego gestu inny aktor”19.

Trzecia część Traktatu o manekinach zawiera dokończenie wykładu. Jakub dookreśla, jak miałyby powstawać i wyglądać istoty, które zamierza stworzyć. Chce, aby były bezkształtne; z pozoru podobne do istot żywych, organiczne - ale tylko w połowie, ponadto - ruchliwe i wrażliwe na bodźce. Nazywa je mianem: „generatio aequivoca”; tzn. „samorództwo”. Maja powstawać w wyniku „fantastycznej fermentacji materii” ${ }^{20}$ lub na skutek połączenia koloidów z roztworem soli kuchennej. Jednak Jakub, ze względu na ciekawsze efekty, preferuje pierwszy sposób ich uzyskiwania. Jak podaje - najlepszą glebą dla „fermentowania materii” są stare mieszkania wypełnione marzeniami, wspomnieniami, tęsknotami, czy nudą, dawnych ich użytkowników. Na takim gruncie „pseudowegetacja”, zarówno - bardzo szybko rozkwita, jak i - więdnie. Bohater opowiada swoje wrażenia z wizyty w takim zapomnianym pomieszczeniu. Właśnie tam - w szarym powietrzu pokoju - objawiła mu się wiosna w pełnym rozkwicie, a raczej symulacja wiosny, gdyż: „Cała ztudna ta fatamorgana byta tylko mistyfikacja, wypadkiem dziwnej symulacji materii, która podszywa sie pod pozór życia."21

Taki zapomniany pokój można skojarzyć z jednym z poziomów psychiki, które wyodrębnił Zygmunt Freud - z podświadomością, gdyż to ona jest źródłem ludzkich popędów, tłumionych pragnień czy marzeń. To właśnie z podświadomości artysta (często nieświadomie) czerpie natchnienie do tworzenia swoich dzieł. To jest materiał („materia”). Taki sam pogląd przedstawił w swoim dziele Marcel Proust: „Wtedy, mniej zapewne olśniewajaca od światta, dzięki któremu spostrzegtem, że dzieto sztuki to jedyny sposób, aby odnaleźć Czas utracony, nowa świattość stata się we mnie. I pojątem, że całe tworzywo dzieta literackiego to moje życie minione; pojatem, że tworzywo to przychodziło do mnie wśród błahych uciech, w godzinach lenistwa, w momentach tkliwości $i$ bólu $i$ że magazynowatem to wszystko ani się domyślajac, $w$ jakim dziatam celu, nie spodziewajac sie nawet, że przetrwaja te zapasy $i \dot{z}$ e w ziarnie tym gromadzi sie wszelki pokarm, który wyżywi rośline." 22

W kontekście tego fragmentu można stwierdzić, że materia (wspomnienia, sny, marzenia) jest materiałem, z którego tworzona jest „pseudomateria” („wiosna” wraz z budząca się do życia roślinnością). Innymi słowy - dzieło literackie („roślina”) powstaje („żywi się”) przeszłością zmagazynowaną w umyśle twórcy („piszącego”).

18 PROUST, Marcel: W poszukiwaniu straconego czasu. T. VII. Tłum. Julian Rogoziński. Warszawa: PIW, 1960, s. 216.

20 Ibidem, s. 40.

21 Ibidem, s. 43.

22 PROUST, Marcel: Op. cit., s. 215. 
W kolejnej części opowiadania Jakub precyzuje swoje zainteresowania w kwestii twórczego materiału: „Fascynowaty go formy graniczne, watpliwe i problematyczne, jak ektoplazma somnambulików, pseudomateria, emancja kataleptyczna mózgu, która w pewnych wypadkach rozrastata się z ust uśpionego na caty stót, napetniata caty pokój, jako bujajaca rzadka tkanka, astralne ciasto, na pograniczu ciała $i$ ducha." ${ }^{23}$

Warto zwrócić uwagę, że Carl Gustav Jung używał podobnej symboliki opisując istotę archetypów. Jak podaje Elżbieta Sarnowska-Temeriusz - porównywał je do „[...] niewidzialnej, ultrafioletowej czéści widma fizycznego". ${ }^{24} \mathrm{~W}$ kontekście teorii Junga to zbiorowa nieświadomość, będąca źródłem archetypów, byłaby materią, o której mówi Jakub. Świadczyłby o tym początek jego trzeciej prelekcji, w którym dopowiada, że materia jest obdarzona pamięcią, a kształty, które przyjmuje, mają tendencję do powtarzania się ${ }^{25}$. Innymi słowy - istnieje pewien ograniczony zasób form (archetypów), poprzez które się przejawia. W teorii Junga rolę twórcy przyjmuje świadomość, która jest w stanie przekształcić czystą treść archetypiczną w archetypiczny obraz - symbol. Z kolei w poecie Jung widzi wyraziciela tych archetypowych znaczeń: „Nic bardziej mylacego niż przyjać, że poeta tworzy w oparciu o tradycyjny materiat. On raczej czerpie z praprzeżycia, którego ciemna natura wymaga figury mitologicznej $i$ dlatego chciwie przyciaga do siebie to, co pokrewne, by sie w ten sposób wyrazić." 26

Materię postulowaną przez Jakuba, w oparciu o koncepcję Coleridge‘a, można też utożsamić z fantazją. Coleridge definiuje wyobraźnię jako pewnego rodzaju pamięć, która nie zna ograniczeń, zarówno jeśli chodzi o czas, jak i - przestrzeń, a poza tym - jako pamięć, która ma tendencję do igrania z „[...] tym, co state $i$ określone $[\ldots .$.$] . { }^{27}$

I tak widzimy jak Jakub, w toku swoich wykładów, przechodzi od ducha do materii, a w rezultacie postuluje „coś, co byłoby pomiędzy”, coś na pograniczu tych dwóch światów. Może to być symbol, gdyż „[...] taczy w sobie to, co dostępne $i$ jawne, z niedostępnym i utajonym”" czyli pośredniczy między duchem a materią. Może być - „słowo”: „W mowie poety skupia się to, co wewnętrzne, co znaczeniem zatopione w umyśle, i to, co zewnętrzne: energia dźwiękowa $i$ znaczeniowa, która rozbrzmiewa $i$ wchodzi w zwiazki ze światem. Wiersz uczyniony jest z duszy znaczeń $i$ z ciała dźwięków, ma cechy osobowe, przy jego lekturze - bardziej niż przy lekturze innych stownych tworów - mamy odczucie źródtowego obcowania z cztowiekiem, a nie ze zlepkiem stów naśladujacych czyjaśs duchowość. Poeta wyprawia wiersz w świat, jakby posytat cztowieka równego sobie, dziatajacego w jego imieniu, ale przecież osobnego, wolnego." ${ }^{29}$

Zatem, odnosząc te słowa do koncepcji Jakuba, można uznać, że postulując wtóre stworzenie człowieka - manekina, mówi o tworzeniu poezji; wierszy lub postaci literackich,

23 SCHULZ, Bruno: Op. cit., s. 43-44.

24 SARNOWSKA-TEMERIUSZ, Elżbieta: Mitograficzne orientacje w badaniach literackich. W: Stownik literatury polskiej XX wieku. Red. Janusz Sławiński. Wrocław: Zakład Narodowy im. Ossolińskich, 1992, s. 648.

25 SCHULZ, Bruno: Op. cit., s. 41.

26 SARNOWSKA-TEMERIUSZ, Elżbieta: Op. cit., s. 649.

27 FRYE, Northrop: Op. cit., s. 298.

28 SARNOWSKA-TEMERIUSZ, Elżbieta: Op. cit., s. 648.

29 MATYWIECKI, Piotr: Dwa oddechy. Szkice o tożsamości żydowskiej i chrześcijańskiej. Warszawa: Więź, 2010, s. 15 . 
czy też symboli archetypicznych. Słowa nie tylko stwarzają (przywołują) w umyśle obrazy, czyli „podszywają się pod pozór życia”, ale także porządkują chaos świata, a tym samym stwarzają go na nowo, po raz „wtóry”, w ludzkim umyśle. Podobne idee wyznaje Jung: "[...] wiedziatem, że cztowiek jest niezbędny, by dopetnić dzieto stworzenia, mato tego - teraz wiedziatem, że sam jest drugim stwórca, bo dopiero on nadaje istnieniu obiektywny byt, bez którego świat toczytby sie przez setki milionów lat w najgtębszej nocy niebytu ku swemu nieokreślonemu końcowi - nie styszany, nie widziany, niemo żrac, rodzac, umierajac i potrzasajac gtowa. Dopiero ludzka świadomość stworzyta obiektywny byt i sens, dzięki czemu cztowiek znalazt swe miejsce w wielkiej ewolucji bytu." ${ }^{30}$

W końcowej części Traktatu o manekinach Jakub ponownie wspomina o cierpieniu materii; tym razem nieszczęśliwej, bo pozbawionej przez człowieka tożsamości. Jako przykład podaje szafy, które będąc efektem „ukrzyżowania” różnych gatunków drzew, „nienawidzą”. Bohater wspomina również o dawnym plemiennym zwyczaju balsamowania zwłok i trzymania ich w domu, co można zrozumieć jako jego opinię na temat utrwalania portretów bliskich ludzi w literaturze. Podobnie wyraził się o tym Marcel Proust: „[...] ksią̇ka to ogromny cmentarz, gdzie na większości grobów nie odczytasz nazwisk już zatartych. Czasem, przeciwnie, pamiętamy doskonale nazwisko, nie wiedzac jednak, czy na tych kartkach przetrwa coś z istoty, która je nosita." ${ }^{1}$

Na koniec Jakub, zanim Adela uciszy go gestem łaskotania, opowie jeszcze o przemianie jego brata w „zwój gumowych kiszek”. W innych opowiadaniach czytamy, że Jakub też podlegał takim zaskakującym metamorfozom; w kondora, karakona (Karakony), czy kraba. Choć za każdym razem tracił dotychczasową zewnętrzną „formę”, to jednak w świadomości rodziny nadal zachowywał swą wewnętrzną istotę, tożsamość; nadal był ojcem Józefa, głową rodziny. Przemiany Jakuba wydają się czymś fantastycznym, ale dla nas - ludzi współczesnych. Lucien Lévy-Bruhl wykazał, że pierwotne społeczności inaczej postrzegały i klasyfikowały rzeczywistość. Ich sposób myślenia określił mianem - „prelogicznego"32. Jako przykład podał Indian Bororo, którzy twierdzili, nie dostrzegając w tym żadnej sprzeczności, że są zarazem ludźmi i czerwonymi ptakami. I nie chodzi tu o nadanie nazwy, czy wykazanie pokrewieństwa z owymi zwierzętami. Chodzi o pokazanie pewnej „esencjonalnej tożsamości”, jaka ich łączy z tymi ptakami ${ }^{33}$. Jak wyraźnie widać, ten sposób myślenia można odnieść do omawianych tu metamorfoz Jakuba. Można także dopatrzyć się w tych „identyfikacjach” zabiegów charakterystycznych dla konstrukcji mitu. Otóż, mit posługuje się dwoma zasadami: analogii i tożsamości ${ }^{34}$. W tym przypadku zastosowanie ma druga z reguł, gdyż zestawia ze sobą (z pozoru) odmienne pojęcia, między którymi dostrzega jakąś analogię, tym samym przypisując rzeczom lub osobom nową, lub dodatkową, tożsamość. Przykładem może tu być, często występująca w pierwotnych kulturach, identyfikacja boga ze słońcem: „bóg - słońce”. Tym samym Jakub

30 JUNG, Carl Gustav: Wspomnienia, sny, myśli. Spisane i podane do druku przez Aniele Jaffé. Tłum. Robert Reszke i Leszek Kolankiewicz. Warszawa: WROTA, 1997, s. 238.

31 PROUST, Marcel: Op. cit., s. 219.

32 CZEREMSKI, Maciej: Struktura mitów. W strone metonimii. Kraków: NOMOS, 2009, s. 33-34.

33 Ibidem, s. 33.

34 FRYE, Northrop: Op. cit., s. 300. 
- kondor, czy Jakub - karakon, jako postać mityczna (tzn. z mitologii Schulza) przestaje dziwić. I być może „manekin” w „schulzowskim słowniku” jest określeniem właśnie na tę „esencjonalną tożsamość”.

Te krótkie utwory, składające się na Traktat o manekinach, to jakby fragment zaginionej wtórej Biblii autorstwa Jakuba. Sa niczym „szpargat” odnaleziony przez Józefa - zagubione wśród opowiadań Brunona Schulza.

\section{Bibliografia}

CZEREMSKI, Maciej: Struktura mitów. W stronę metonimii. Kraków: NOMOS, 2009.

CZYŻEWSKI, Tytus: Pogrzeb romantyzmu - uwiad starczy symbolizmu - śmierć programizmu. W: Antologia polskiego futuryzmu i Nowej Sztuki. Oprac. Zbigniew Jarosiński i Helena Zaworska. Wrocław: Zakład Narodowy im. Ossolińskich, 1978.

FRYE, Northrop: Mit, fikcja i przemieszczenie. W: Studia z teorii literatury. Archiwum przektadów»Pamiętnika Literackiego«. Wrocław: Zakład Narodowy im. Ossolińskich, 1977.

JARZĘBSKI, Jerzy: Czasoprzestrzeń mitu i marzenia w prozie Brunona Schulza. W: tegoż: Powieś́ jako autokreacja. Kraków: Wydawnictwo Literackie, 1984.

JUNG, Carl Gustav: Wspomnienia, sny, myśli. Spisane i podane do druku przez Aniele Jaffé. Tłum. Robert Reszke i Leszek Kolankiewicz. Warszawa: WROTA, 1997.

KOPALIŃSKI Władysław: Stownik symboli. Warszawa: Rytm, 2001.

LACHMANN, Renate: Demiurg i jego fantazmaty. Spekulacje wokót mitologii stworzenia w dziele Bruno Schulza. Tłum. Jan Balbierz. Teksty Drugie, 1999, nr 6.

MATYWIECKI, Piotr: Dwa oddechy. Szkice o tożsamości żydowskiej i chrześcijańskiej. Warszawa: Więź, 2010.

PANAS, Władysław: Topika judajska. W: Stownik literatury polskiej XX wieku. Red. Janusz Sławiński. Wrocław: Zakład Narodowy im. Ossolińskich, 1992.

PROUST, Marcel: W poszukiwaniu straconego czasu. T. VII. Tłum. Julian Rogoziński. Warszawa: PIW, 1956.

SARNOWSKA-TEMERIUSZ, Elżbieta: Mitograficzne orientacje w badaniach literackich. W: Stownik literatury polskiej XX wieku. Red. Janusz Sławiński. Wrocław: Zakład Narodowy im. Ossolińskich, 1992.

SCHULZ, Bruno: Opowiadania. Wybór esejów i listów. Kraków: Zakład Narodowy im. Ossolińskich, 1989.

\section{Mgr. Maria Olędzka}

Katedra slavistiky

Filozofická fakulta, Univerzita Palackého v Olomouci

Krrǐžkovského 10, 77180 Olomouc, Česká republika

maria.oledzka01@upol.cz 
